\title{
Distraction-related road traffic collisions
}

\author{
Hani O Eid ${ }^{1}$, Fikri M Abu-Zidan ${ }^{1,2}$
}

1. Department of Surgery, College of Medicine and Health Sciences, UAE University, Al-Ain, United Arab Emirates

2. Department of Surgery, Al-Ain Hospital, Al-Ain, UAE

\begin{abstract}
Objectives: We aimed to prospectively study distraction-related road traffic collision injuries, their contributory factors, severity, and outcome.

Methods: Data were prospectively collected on all hospitalized road traffic collision trauma patients in Al-Ain City who were drivers at the collision time over one and half years. Driver's inattentive behaviors preceding the collision were collected by interviewing the admitted drivers.

Results: There were 444 drivers, 330 of them were fully oriented patients, out of them only $44(13 \%)$ were distracted. Nineteen $(5.8 \%)$ drivers were distracted by using mobile phones, 12 (3.6\%) were pre-occupied with deep thinking, six $(1.8 \%)$ were talking with other passengers, four $(1.2 \%)$ were picking things in the vehicle, and three $(0.9 \%)$ were using entertainment systems. The maximum distraction occurred during the time of 6 am - 12 noon when the traffic was crowded. There were no significant differences between distracted and non-distracted drivers in demographical and physiological factors, injured regions, and outcomes. Conclusion: Distraction of alert drivers causes 13\% of road traffic collisions in Al-Ain city. About 40 percent of the distracted drivers involved in road traffic collisions (RTC) were using mobile phones. Our study supports the ban of use of cell phones while driving.
\end{abstract}

Keywords: Distraction, prevention, road traffic collision, mobile phone.

DOI: https://dx.doi.org/10.4314/ahs.v17i2.24

Cite as: Eid HO, Abu-Zidan FM. Distraction-related road traffic collisions. Afri Health Sci. 2017;17(2): 491-499. https://dx.doi. org/10.4314/abs.v17i2.24

\section{Introduction}

Road traffic collisions (RTC) continue to be a global public health problem. RTC was the ninth leading cause of death in 2004. The World Health Organization (WHO) has recently predicted that RTC will move to be the fifth leading cause of death in $2030^{1}$. In 2007, RTC death rates were estimated to be 37.1 per 100,000 population in the United Arab Emirates (UAE), which was one of the

\section{Corresponding author:}

Fikri M Abu-Zidan,

FACS, FRCS, Dip Appl Statistics, Consultant Surgeon

(Trauma, Acute Care, and Disaster Medicine),

Point-of-Care Sonographer, and Statistical Consultant

Department of Surgery,

College of Medicine and Health Sciences, UAE University

PO Box 17666, Al Ain

Tel 0097137137579

Fax: 0097137672067

E-mail: fabuzidan@uaeu.ac.ae highest in the world ${ }^{1}$. Furthermore, RTC was responsible for more than $75 \%$ of unintentional injury deaths in the UAE and ranked as the second cause of death after cardiovascular diseases ${ }^{2,3}$.

The rapid development in the era of technology forces us to be connected with others wherever we are. Furthermore, the pressure of time led us to combine multiple tasks to save time. Our behaviors became automated beyond our thoughts. Performing a secondary task will distract us from the primary task. Distraction while driving is a sprouting serious road safety issue that causes a proportion of preventable death $s^{4,5}$. Pre-crash driver's distraction was reported to be responsible for about $80 \%$ of collisions and $65 \%$ of near-collisions ${ }^{6}$. We aimed to prospectively study distraction-related road traffic collision injuries, their contributory factors, severity, and outcome in Al-Ain city, UAE, so as to give recommendations on preventive priorities.

\section{Materials and methods}

The data of the Road Traffic Collision (RTC) injury regis- 
try of Al-Ain city was prospectively collected from April 2006 to October 2007. All patients who were admitted to Al-Ain and Tawam Hospitals, or who died in the Emergency Departments after being involved in a road traffic collision were included in the registry. These are the only two hospitals admitting road traffic injured patients in Al-Ain city. Al-Ain city has a population of about half a million ${ }^{7}$. A full time Trauma Research Fellow (HOE) was responsible for interviewing the RTC injured patients or their relatives soon after hospital admission. The patients were followed up until being discharged from the hospital. Patients with decreased level of consciousness at the time of admission were interviewed during their hospital stay when they regained their consciousness and were able to recall the collision and answer questions.

The data collected included demographic data, time of collision, and distraction of the driver. Distraction was defined as diversion of attention away from activities critical for safe driving, toward a competing activity, which results in insufficient or no attention to these critical activities ${ }^{8}$. Studied specific driver's inattentive behaviors preceding the collision included: using mobile phones, talking with other passengers, using an entertainment system, eating or drinking, smoking, and other behaviors reported by them. These behaviors were collected by interview using a structured checklist form with "Yes", "No" or "Unknown" choices. Drivers who had sleep-related collision, those who were under influence of alcohol or illicit drugs in the last twenty four hours before collision, or those with missing data on their attention before the collision mainly because of continued loss of consciousness were excluded from the study.

Approval for data collection was obtained from the Local Ethics Committee of Al-Ain Health District Area (ethical approval No: RECA/02/44). Injury severity was scored using the Anatomical Injury Score (AIS) and the Injury Severity Score (ISS) ${ }^{9}$. The ISS was calculated manually, using the Abbreviated Injury Scale Handbook, as the sum of squares of the three highest AIS scores from the six different body regions. The Revised Trauma Score (RTS) was calculated. It is a physiological scoring system depending on Glasgow Coma Scale (GCS), systolic blood pressure and respiratory rate, and has a scale from zero to $12^{10}$. Lower RTS or GCS indicates a worse clinical condition of the patient.

\section{Statistics}

Patients were divided into two groups; the distracted drivers group and the non-distracted drivers group. Continuous or ordinal data was analyzed using Mann-Whitney U test while categorical data was analyzed using Fisher's exact test. Data was analyzed with PASW Statistics 20 software, (SPSS, Chicago, IL, USA). For all analyses, a p value of less than 0.05 was considered significant.

\section{Results}

The total number of RTC injured patients in our registry was 1,008 patients, 444 (44\%) were vehicle drivers. 75 patients had missing data on their behavior before the collision. Out of the 369 (83\%) remaining drivers with complete data; 24 had sleep-related collisions, and 15 were under the influence of alcohol or drugs and were excluded. The 330 remaining fully oriented patients were included in the study, out of them only $44(13 \%)$ drivers were distracted before the crash (Table 1). The median (range) age of the distracted patients was 28 (16-57) years. Fourteen $(32 \%)$ of them were using a seat belt. Table 1 shows the demography of the distracted and non-distracted drivers. There were no significant differences between the two groups in age, gender, nationality, seat belt usage, or death on the scene of an accompanying passenger. 
Table 1. Demography of vehicle drivers injured in road traffic collisions comparing those who were distracted with those who were not

\begin{tabular}{|c|c|c|c|}
\hline Variable & $\begin{array}{l}\text { Distracted } \\
\mathrm{n}=44\end{array}$ & $\begin{array}{l}\text { Non-Distracted } \\
n=286\end{array}$ & $\mathrm{P}$ value \\
\hline Age (years) & $28(16-57)$ & $28(16-78)$ & 0.22 \\
\hline \multicolumn{4}{|l|}{ Gender } \\
\hline Male & $40(91 \%)$ & $254(89 \%)$ & \multirow{2}{*}{0.8} \\
\hline Female & $4 \quad(9 \%)$ & $32(11 \%)$ & \\
\hline \multicolumn{4}{|l|}{ Nationality } \\
\hline UAE & $27(61 \%)$ & $138(48 \%)$ & \multirow[t]{2}{*}{0.14} \\
\hline Non UAE & $17(39 \%)$ & $148(52 \%)$ & \\
\hline \multicolumn{4}{|l|}{ Seat belt } \\
\hline Restrained & $14(32 \%)$ & $83(29 \%)$ & \multirow[t]{2}{*}{0.72} \\
\hline Not restrained & $30(68 \%)$ & $203(71 \%)$ & \\
\hline Death on scene & $0(0 \%)$ & $1(0.3 \%)$ & 0.99 \\
\hline
\end{tabular}

Data presented as median (range) or numbers (\%) as appropriate.

$\mathrm{P}$ value $=$ Fisher's Exact test or Mann-Whitney $\mathrm{U}$ test as appropriate .

Table 2 shows the type of distraction of the drivers prior to crash. $19(5.8 \%)$ of the drivers were distracted by using mobile phones, $12(3.6 \%)$ were pre-occupied with deep thinking, six $(1.8 \%)$ were talking with other passengers, four $(1.2 \%)$ were picking up things in the vehicle, and three $(0.9 \%)$ were using entertainment systems.

Table 2. Types of distraction for drivers involved in RTC in Al-Ain city, UAE

\begin{tabular}{|lll|}
\hline Variable & $\begin{array}{l}\text { Number } \\
\mathrm{n}=44\end{array}$ & $\%$ \\
\hline Using mobile phone & 19 & 5.8 \\
Preoccupation with deep thinking & 12 & 3.6 \\
Talking with other passengers & 6 & 1.8 \\
Handling things while driving & 4 & 1.2 \\
Using an entertainment system & 3 & 0.9 \\
\hline Data presented as numbers (\%). & & \\
\hline
\end{tabular}

Table 3 shows the distribution and severity of injuries comparing the two groups of drivers. The most common injured region was the thorax, $(41 \%)$, followed by the face
$(39 \%)$, and head $(34 \%)$. There were no significant differences between the injured anatomical regions of the two groups. 
Table 3. Anatomical regions and severity of injury of vehicle drivers injured in road traffic collisions comparing those who were distracted with those who were not

\begin{tabular}{|lllllll|}
\hline Region & $\begin{array}{l}\text { Distracted } \\
\mathbf{n}=\mathbf{4 4}\end{array}$ & $\begin{array}{l}\text { Non-Distracted } \\
\mathbf{n = 2 8 6}\end{array}$ & P value & $\begin{array}{l}\text { Distracted } \\
\text { AIS }\end{array}$ & $\begin{array}{l}\text { Non- } \\
\text { Distracted } \\
\text { AIS }\end{array}$ & P value \\
\hline Head & $15(34 \%)$ & $128(45 \%)$ & 0.24 & $2(1-4)$ & $2(1-5)$ & 0.94 \\
Face & $17(39 \%)$ & $96(34 \%)$ & 0.61 & $1(1-2)$ & $1(1-2)$ & 0.69 \\
Neck & $3(6.8 \%)$ & $29(10 \%)$ & 0.71 & $1(1-1)$ & $1(1-2)$ & 0.99 \\
Thorax & $18(41 \%)$ & $108(38 \%)$ & 0.99 & $1(1-4)$ & $2(1-4)$ & 0.12 \\
Abdomen & $5(11 \%)$ & $44(15 \%)$ & 0.66 & $1(1-2)$ & $1(1-5)$ & 0.29 \\
Spine & $8(18 \%)$ & $40(14 \%)$ & 0.59 & $2(2-3)$ & $2(1-5)$ & 0.39 \\
Upper Extremity & $15(34 \%)$ & $96(34 \%)$ & 0.99 & $2(1-3)$ & $1(1-3)$ & 0.2 \\
Lower Extremity & $14(32 \%)$ & $83(29 \%)$ & 0.82 & $1.5(1-3)$ & $2(1-4)$ & 0.69 \\
\hline
\end{tabular}

Data presented as median (range) or numbers (\%) as appropriate.

$\mathrm{P}$ value $=$ Fisher's Exact test or Mann-Whitney U test as appropriate.

Table 4 shows the physiological and anatomical markers of injury severity of distracted and non-distracted drivers. There were no statistically significant differences between the two groups in pulse, systolic blood pressure, Glasgow Coma Scale (GCS), ISS, RTS, hospital stay, and mortali- ty. Eight distracted drivers were admitted to the intensive care unit (ICU), none of them died. There was a trend for difference in distraction time as majority of distractions occurred at 6:00 am to $6: 00 \mathrm{pm}(64 \%)$ compared with $(36 \%)$ at $6: 00 \mathrm{pm}$ to $6: 00 \mathrm{am}(\mathrm{p}=0.067)$ (Figure 1). 
Table 4. Markers of injury severity of vehicle drivers injured in road traffic collisions comparing those who were distracted with those who were not

\begin{tabular}{llll}
\hline Variable & $\begin{array}{l}\text { Distracted } \\
\mathrm{n}=44\end{array}$ & $\begin{array}{l}\text { Non-Distracted } \\
\mathrm{n}=286\end{array}$ & P value \\
\hline Pulse (bpm) & $89.5(60-130)$ & $91(47-165)$ & 0.3 \\
Systolic blood pressure (mmHg) & $135(103-160)$ & $133(85-190)$ & 0.97 \\
GCS & $15(5-15)$ & $15(5-15)$ & 0.44 \\
ISS & $4.5(1-29)$ & $5(1-50)$ & 0.49 \\
RTS & $12(9-12)$ & $12(7-12)$ & 0.45 \\
Total hospital stay (days) & $3(1-32)$ & $3(1-127)$ & 0.95 \\
ICU admission & $8(18 \%)$ & $40(14 \%)$ & 0.49 \\
Death & $0(0 \%)$ & $1(0.3 \%)$ & 0.99 \\
\hline
\end{tabular}

Data presented as median (range) or numbers (\%) as appropriate.

$\mathrm{P}$ value $=$ Fisher's Exact test or Mann-Whitney U test as appropriate .

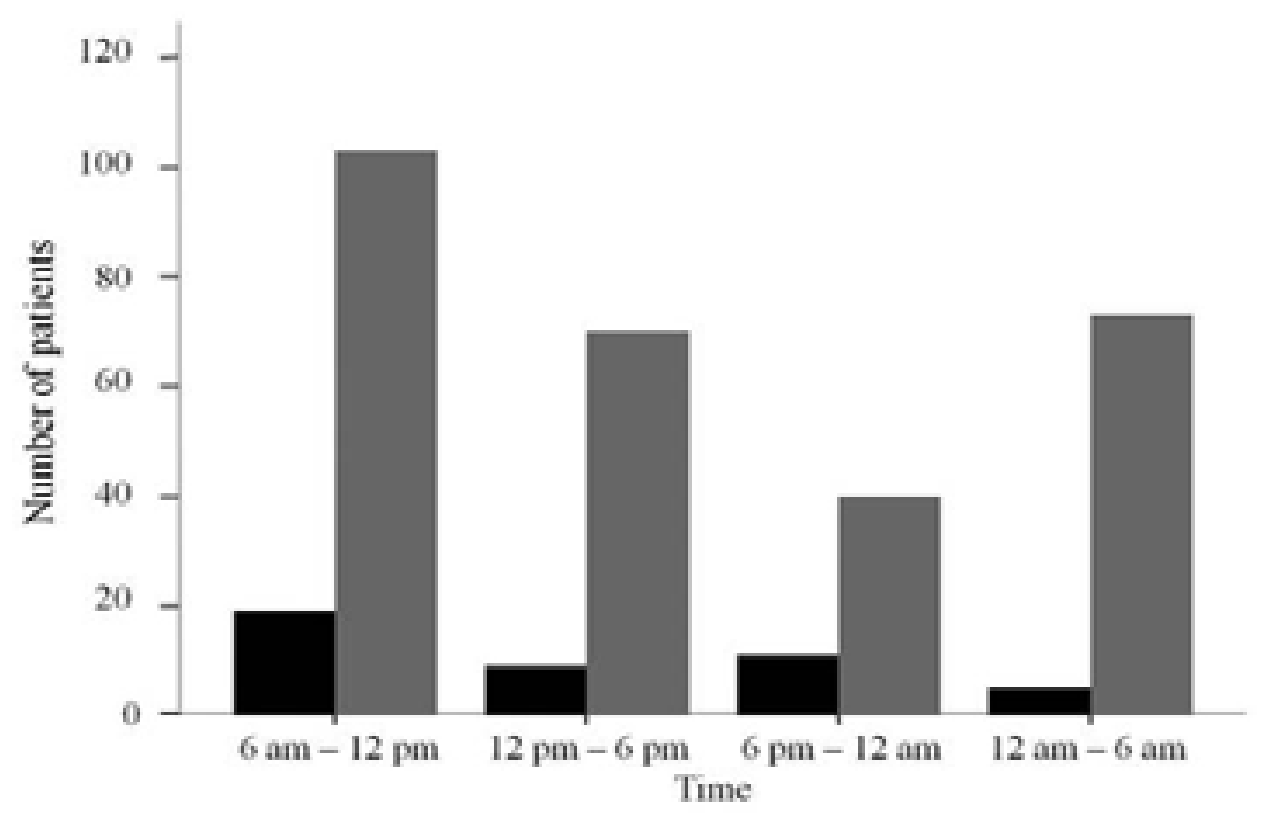

Figure 1:

Time of road traffic collisions comparing those who were distracted (black bars) and those who were not (grey bars) 


\section{Discussion}

Our present study shows that distraction-related road traffic collisions of alert drivers occurred in $13 \%$ of all hospitalized RTC injured drivers. Majority of them were middle-aged males. The most common distraction behaviors were; using a mobile phone, being pre-occupied by thinking, talking with other passengers, handling things inside the vehicle, and using the entertainment systems. We excluded alcohol, drug, and sleep-related RTC because we aimed to assess the effects of distraction on fully alert drivers. There were no differences in the demography of distracted and non-distracted vehicle groups.

To our knowledge, our study is the only outcome study in the literature of hospitalized RTC injured drivers comparing distracted and non-distracted fully alert vehicle drivers. Authors from France stated that their two observational epidemiological studies were the first to assess the risk of RTC related to driver's distraction in the Emergency Departments. They found that distraction caused 8 to $17 \%$ of RTCs ${ }^{11,12}$.

The use of cell phones while driving is a growing risk factor for motor vehicle collisions ${ }^{4,5}$. Telecommunication keeps us connected with others with great advantages. Nevertheless, this has increased the injury and death on roads ${ }^{4}$. Using a cell phone was the main distracter in our injured patients. Others have supported our finding ${ }^{6,13,14}$. Using a cell phone while driving increases the risk of having a road traffic collision by fourfold ${ }^{15}$. The use of mobile phones without headsets while driving is illegal and banned by UAE traffic law. Offender drivers get 55 USA dollar fine and four black points on their driving record. Despite that, using mobile phones while driving continues to be a very popular offending behavior in the country.

The second common distracter for drivers in our study was mind wandering. Thinking deeply beyond the driving task will distract the driver and increase the risk of RTCs. An observational study has shown that more than half of the drivers who had a RTC had some degree of mind wandering before collisions ${ }^{12}$. Similar to our study, a survey from Sweden showed that $3.2 \%$ of drivers who were involved with RTC's were distracted by deep thinking ${ }^{16}$. Six $(1.8 \%)$ drivers in our study reported being distracted by talking with other passengers. The degree of distraction is affected by the age and gender of both drivers and passengers ${ }^{17}$. In general, drivers who are accompanied by other passengers drive more safely because direct conversation has a protective effect ${ }^{5,17,18}$. Nevertheless, young drivers are more prone to have a crash in the presence of other young passengers.

Picking an object and using an entertainment system was associated with $2.1 \%$ of the distraction-related collisions in our study. Stutts et al showed that reaching or searching for an object and manipulating the vehicle controls are the most common distracters inside the vehicle ${ }^{19}$. Hoff et al found that half of the drivers were distracted by reaching an object ${ }^{14}$.

We have noticed that distraction-related RTC were more during the morning time while it was less after the midnight (Fig 1). The traffic is more crowded in the morning in our city than after midnight. It is possible that this occurred because any minor distraction in a crowded traffic may lead to a collision.

Prevention of distraction-related RTC is demanding. Although there are numerous studies on the effects of distraction on the driver's behavior, there is no scientific evidence to support the effectiveness of prevention measures $^{20}$. Banning the use of hand-held cell phones during driving is controversial. Although legislation to ban use of cell phones during driving has been adopted by many countries, such law was not adopted by Sweden which is a pioneer country in road safety. This stemmed from difficulties in enforcement of the law and detection of violators ${ }^{20,21}$.

The use of hands-free phones does not have advantages over the hand-held ones because both have the same effect on driver's distraction ${ }^{22,23}$. The only benefit gained from banning the use of hand-held phones is reducing texting while driving (TWD). TWD causes physical, cognitive, and visual distraction to the driver which is more dangerous than a phone conversation ${ }^{24}$. An increase in texting was associated with an increase in road fatalities ${ }^{25}$. Banning the use of cell phones and TWD should also be accompanied by strict and regular law enforcement ${ }^{25,26}$. A study using functional magnetic resonance imaging evaluated the impact of concurrent listening on the brain activity on simulated driving. Listening distracted concentration during driving and deteriorated the driving performance. Using the cell phone disrupts driving perfor- 
mance even without holding or dialing a phone ${ }^{27}$. Health awareness and education is an important component in injury prevention and campaigns for safety promotion are effective measures that should precede law enforcement.

A study from the United States showed that $66 \%$ of young drivers used cell phones ${ }^{23}$. Another recent systemic review indicated that young drivers are more distracted by using cell phones ${ }^{26}$. Young drivers usually have risky behaviours and less compliance to traffic safety regulations $^{28}$. There was no difference in the age between those who were distracted and those who were not in our study. This is explained by the fact that the UAE population is a young population and such difference is not anticipated. Only $1.7 \%$ of the UAE population and $4 \%$ of the hospitalized trauma patients are 60 years or older ${ }^{29}$.

\section{Limitations of the study}

We have to acknowledge that our study has certain limitations. Data on drivers' distraction in our study was collected by self-reporting using close ended questions in our data collection form. Using open ended questions in a specific study or survey may help in gathering more information. Our study was part of a registry studying RTC where simple ended questions were used. These results may not reflect the real status of distraction-related collisions in our city because some drivers did not possibly report these behaviors. Moreover, inability to completely recall the pre-crash event may affect the reporting of distraction.

Our study had a small sample size in the distracted group. This possibly led to type II statistical error (missing significance which was present). The power of the study could have been increased by increasing the study sample size. Nevertheless, our study represents all drivers who were hospitalized following road traffic collisions over a period of 18 months in a city having half a million population.

Furthermore, we have only studied hospitalized patients in our city. Many drivers with RTC injuries were treated at the Emergency Department without being admitted to the hospital. A recent observational study which was conducted through online survey in UAE has shown that $60 \%$ of the drivers reported using mobile phones while driving ${ }^{30}$. The studied population ${ }^{30}$ is different from ours. Our subjects were those who were actually using phones when they were involved in RTC compared with the other study which reported the percentage of drivers who use cell phones but not necessarily being involved in $\mathrm{RTC}^{30}$. Our patients represent the tip of the iceberg of the problem of using cell phones while driving with the maximum impact of error but not the near miss error.

The reason why there was no significance between the two hospitalized groups could be selection bias. Severely injured patients were admitted to the hospital while less severe patients were treated at the Emergency Department and discharged home. This possibly led to similar severity between the two hospitalized groups.

Data on texting, which is important, is missing in our study. Although our study was prospective, we did not collect that data because its value was not clear in the literature when we performed our study. Our study, which was performed during 2006-2007, was a specific time limited research project supported by the UAE University. Texting while driving contributes to increased driving fatalities $^{25}$. There is a need for a future prospective detailed study on distraction-related RTC in our community so as to better understand the drivers' behaviors in our setting. We should include these missing variables in any future prospective study. Despite these limitations, we think that the findings of our study are important. Missing variables is a very common limitation when studying RTCs. This limitation is acceptable, and should not prevent us from making safety recommendations depending on the best available evidence ${ }^{31}$.

\section{Conclusion}

Distraction of alert drivers causes $13 \%$ of road traffic collisions in Al-Ain city. Injured hospitalized distracted drivers share the same injury severity as non-distracted drivers. Our study supports the ban of use of cell phones while driving and highlights the importance of not being distracted when driving.

\section{Acknowledgement}

This study was supported by an Interdisciplinary UAE University grant Grant (\#02-07-8-1/4).

\section{Conflict of interest statement}

All authors declare that they have no conflicts of interest.

\section{References}

1. World Health Organization. Global status report on 
road safety: time for action. Geneva, World Health Organization, 2009. Available at: http://whqlibdoc.who.int/ publications/2009/9789241563840_eng.pdf. Accessed 22 December 2013.

2. Ministry of Health. Annual Statistic Report. Ministry of Health,Preventive Medicine Sector, Abu Dhabi, UAE, 2004,p.213-214.

3. Health Authority of Abu Dhabi. Health Statistics. Health Authority of Abu Dhabi, Abu Dhabi, UAE, 2010. Available at: http://www.haad.ae/statistics. Accessed 5 May 2011.

4. World Health Organization. Global status report on road safety. Geneva, World Health Organization. 2013. Available at: http://www.who.int/iris/bitstre am/10665/78256/1/9789241564564_eng.pdf. Accessed 22 December 2013.

5. Lee VK, Champagne CR, Francescutti LH. Fatal distraction: cell phone use while driving. Can Fam Physician 2013;59:723-725 PubMed .

6. Virginia Tech Transportation Institute. 100-car naturalistic study fact sheet. Blacksburg, VA: Virginia Tech Transportation Institute, 2005. Available at: http://www. vtnews.vt.edu/articles/2005/06/2005-834.html.Accessed 6 Jan 2014.

7. Ministry of Health. 2006 Annual report. Ministry of Health, Preventive Medicine Sector, Abu Dhabi, UAE, 2007.

8. Lee JD, Young KL, Regan MA. Defining driver distraction. In: Driver Distraction: Theory, Effects, and Mitigation, CRC Press. Regan M., Lee JD, Young KL (editors). Boca Raton: Taylor \& Francis Group; 2008, pp. 31-40.

9. Association for the Advancement of Automotive Medicine. The Abbreviated Injury Scale 1990 revision - Update 98. Association for the Advancement of Automotive Medicine, Barrington, IL; 1998.

10. Maurer E \& Morris JM. Injury Severity Scoring. In Trauma. $5^{\text {th }}$ edn. Moore EE, Feliciano DV, Mattox KL (editors). NewYork, NY: McGraw-Hill; 2004, pp.87-91. 11. Bakiri S, Galéra C, Lagarde E, Laborey M, Contrand B, Ribéreau-Gayon R, et al. Distraction and driving: results from a case-control responsibility study of traffic crash injured drivers interviewed at the emergency room. Accid Anal Prev 2013;59:588-592 PubMed .

12. Galéra C, Orriols L, M'Bailara K, Laborey M, Contrand $\mathrm{B}$, Ribéreau-Gayon $\mathrm{R}$, et al. Mind wandering and driving: responsibility case-control study. BMJ 2012;13;345: PubMed e8105.

13. Asbridge M, Brubacher JR, Chan H. Cell phone use and traffic crash risk: a culpability analysis. Int J Epidemiol 2013;42:259-267 PubMed .

14. Hoff J, Grell J, Lohrman N, Stehly C, Stoltzfus J, Wainwright $\mathrm{G}$, etal. Distracted driving and implications for injury prevention in adults. J Trauma Nurs 2013;20:3134 PubMed.

15. Redelmeier DA, Tibshirani RJ. Association between cellular-telephone calls and motor vehicle collisions. $N$ Engl J Med 1997;336:453-458 PubMed .

16. Tivesten E, Wiberg H. What can the drivers' own description from combined sources provide in an analysis of driver distraction and low vigilance in accident situations? Accid Anal Prev 2013;52:51-63 PubMed .

17. Lee C, Abdel-Aty M. Presence of passengers: does it increase or reduce driver's crash potential? Accid Anal Prev 2008;40:1703-1712 PubMed .

18. Drews FA, Pasupathi M, Strayer DL. Passenger and cell phone conversations in simulated driving. J Exp Psychol Appl 2008;14:392-400 PubMed .

19. Stutts J, Feaganes J, Rodgman E, Hamlett C, Reinfurt $\mathrm{D}$, Gish $\mathrm{K}$, et al. The causes and consequences of distraction in everyday driving. Annu Proc Assoc Adv Automot Med 2013;47:235-251.

20. World Health Organization. Mobile phone use: a growing problem of driver distraction. Geneva, World Health Organization, 2011. Available at: http://www. who.int/entity/violence_injury_prevention/publications/road_traffic/distracted_driving_summary.pdf. Accessed 25 December 2013.

21. Coben JH, Zhu M. Keeping an eye on distracted driving. JAMA 2013;309:877-878 PubMed .

22. Dragutinovic N,Twisk D. Use of mobile phones while driving - effects on road safety. Leidschendam, Netherlands, SWOV Institute for Road Safety Research, 2005. Available at: https://www.researchgate.net/publication/254116523_Use_of_mobile_phones_while_driving_-_effects_on_road_safety. Accessed 7 January 2014. 23. Braitman KA, McCartt AT. National reported patterns of driver cell phone use in the United States. Traffic Inj Prev 2010;11:543-548 PubMed .

24. Alosco ML, Spitznagel MB, Fischer KH, Miller LA, Pillai V, Hughes J, et al. Both texting and eating are associated with impaired simulated driving performance. Traffic Inj Prev 2012;13:468-475 PubMed .

25. Wilson FA, Stimpson JP. Trends in fatalities from distracted driving in the United States, 1999 to 2008. Am J Public Health 2010;100:2213-2219 PubMed .

26. Cazzulino F, Burke RV, Muller V, Arbogast H, Up- 
perman JS. Cell phones and young drivers: a systematic review regarding the association between psychological factors and prevention. Traffic Inj Prev 2014;15:234-242 PubMed .

27. Just MA, Keller TA, Cynkar J. A decrease in brain activation associated with driving when listening to someone speak. Brain Res. 2008;1205:70-80.

28. Grivna M, Eid HO, Abu-Zidan FM. Youth traffic-related injuries: a prospective study. World J Emerg Surg. 2017;12:2.
29. Hefny AF, Abbas AK, Abu-Zidan FM. Geriatric fall-related injuries. Afr Health Sci. 2016; 16:554-9.

30. Zafar A. $60 \%$ use cell phones while driving. 4 June 2012. khaleejtimes. Available at: http://www.khaleejtimes.com $/ \mathrm{kt}$-article display1.asp? $x$ file $=$ data $/$ nationgen$\mathrm{eral} / 2012 / J u n e /$ nationgeneral_June33.xml\&section=nationgeneral. Accessed 29 June 2014.

31. Savolainen PT, Mannering FL, Lord D, Quddus MA. The statistical analysis of highway crash-injury severities: a review and assessment of methodological alternatives. Accid Anal Prev 2011;43:1666-1676 PubMed . 